American Journal of Environmental Sciences 3 (1): 1-6, 2007

ISSN 1553-345X

(C) 2007 Science Publications

\title{
Effects of Total Dissolved Solids on Aquatic Organisms: A Review of Literature and Recommendation for Salmonid Species
}

\author{
${ }^{1}$ Phyllis K. Weber-Scannell and ${ }^{2}$ Lawrence K. Duffy \\ ${ }^{1}$ Scannell Technical Services, 1235 Schodack Landing Road, Schodack Landing, NY 12156 \\ ${ }^{2}$ Department of Chemistry and Biochemistry, University of Alaska Fairbanks \\ Fairbanks, AK 99775-6160
}

\begin{abstract}
Total dissolves solids (TDS) are naturally present in water or are the result of mining or some industrial treatment of water. TDS contain minerals and organic molecules that provide benefits such as nutrients or contaminants such as toxic metals and organic pollutants. Current regulations require the periodic monitoring of TDS, which is a measurement of inorganic salts, organic matter and other dissolved materials in water. Measurements of TDS do not differentiate among ions. The amount of TDS in a water sample is measured by filtering the sample through a $2.0 \mu \mathrm{m}$ pore size filter, evaporating the remaining filtrate and then drying what is left to a constant weight at $180^{\circ} \mathrm{C}$. The concentration and composition of TDS in natural waters is determined by the geology of the drainage, atmospheric precipitation and the water balance (evaporation-precipitation). The mean salinity of the world's rivers is approximately $120 \mathrm{mg} \mathrm{L}^{-1}$ and the major anion found in natural waters is bicarbonate. The most commonly occurring cation in fresh water is calcium. Changes in TDS concentrations in natural waters often result from industrial effluent, changes to the water balance (by limiting inflow, by increased water use or increased precipitation), or by salt-water intrusion. It is recommended that different limits for individual ions, rather than TDS, be used for salmonid species. These limits should be based on the effect of the ion on fertilization and egg development.
\end{abstract}

Key words: Total Dissolved Solid, TDS, water standards, aquatic organisms, Alaska, salmon

\section{INTRODUCTION}

Total Dissolved Solid (TDS) is a measurement of inorganic salts, organic matter and other dissolved materials in water ${ }^{[1]}$. Measurements of TDS do not differentiate among ions. The amount of TDS in a water sample is measured by filtering the sample through a $2.0 \mu \mathrm{m}$ pore size filter, evaporating the remaining filtrate and then drying what is left to a constant weight at $180^{\circ} \mathrm{C}^{[2]}$. The concentration and composition of TDS in natural waters is determined by the geology of the drainage, atmospheric precipitation and the water balance (evaporation-precipitation) ${ }^{[3]}$. The mean salinity of the world's rivers is approximately $120 \mathrm{mg} \mathrm{L}^{-1}$ and the major anion found in natural waters is bicarbonate, with a mean for all North American river waters of 68 $\mathrm{mg} \mathrm{L}^{-1[3]}$ The second most common anion is sulfate, with a mean concentration of $20 \mathrm{mg} \mathrm{L}^{-1}$. The most commonly occurring cation in fresh water is calcium, with a mean of all North American river waters for which data were available, of $21 \mathrm{mg} \mathrm{L}^{-1}$; the next most commonly occurring cations are sodium and silica, each with an average concentration of $9 \mathrm{mg} \mathrm{L}^{-1[3]}$. Water with total dissolved solids concentrations greater than $1000 \mathrm{mg} \mathrm{L}^{-1}$ is considered to be "brackish". Changes in
TDS concentrations in natural waters often result from industrial effluent, changes to the water balance (by limiting inflow, by increased water use or increased precipitation), or by salt-water intrusion.

Total dissolved solids cause toxicity through increases in salinity, changes in the ionic composition of the water and toxicity of individual ions. Increases in salinity have been shown to cause shifts in biotic communities, limit biodiversity, exclude less-tolerant species and cause acute or chronic effects at specific life stages. Bierhuizen and Prepas ${ }^{[4]}$ found a significant and negative correlation between concentrations of chlorophyll-a (an estimate of primary production) and concentrations of $\mathrm{Na}^{+}, \mathrm{Mg}^{2+}, \mathrm{SO}_{4}{ }^{2-}, \mathrm{HCO}_{3}{ }^{-}$and $\mathrm{CO}_{3}{ }^{2}$. Hallock and Hallock ${ }^{[5]}$ reported substantial changes in marsh communities. When TDS increased from 270 to $1170 \mathrm{mg} \mathrm{L}^{-1}$, both coontail (Ceratophyllus demersum) and cattails (Typha sp.) were nearly eliminated. Derry et al ${ }^{[6]}$ reported that salinity and aquatic biodiversity are inversely related in lake water.

Changes in the ionic composition of water can exclude some species while promoting population growth of others. For example, Derry et al. ${ }^{[6]}$ found that the rotifer Brachionus plicatilis and the harpactacoid copepod Cletocamptus sp. prevailed in lakes with Cl-

Corresponding Author: $\quad$ Lawrence K. Duffy, Department of Chemistry and Biochemistry, Box 756160, University of Alaska Fairbanks, Fairbanks, AK 99775-6160, Tel: 907-474-7525, Fax: 907-474-5101 


\section{Am. J. Environ. Sci. 3 (1): 1-6, 2007}

dominated water. In contrast, the calanoid copepods Leptodiaptoums sicillis and Diaptomus nevadensis were dominant in the $\mathrm{SO}_{4}{ }^{2-} / \mathrm{CO}_{3}{ }^{2-}$-dominated lake water. Mount et al. ${ }^{[7]}$ stated that the composition of specific ions determined toxicity of elevated TDS in natural waters. In general, they found relative ion toxicity was $\mathrm{K}^{+}>\mathrm{HCO}_{3}^{-}=\mathrm{Mg}^{2+}>\mathrm{Cl}^{-}>\mathrm{SO}_{4}{ }^{2-} . \mathrm{Ca}^{2+}$ and $\mathrm{Na}^{+}$did not produce significant toxicity. For C. dubia and $D$. magna, toxicity of $\mathrm{Cl}^{-}, \mathrm{SO}_{4}{ }^{2-}$ and $\mathrm{K}^{+}$were reduced in solutions containing more than one cation.

The diversity of aquatic species decline as osmotic tolerances are exceeded with increasing salinity ${ }^{[6]}$. Concentrations of specific ions may reach toxic levels for certain species of life history stages. Stekoll et al. ${ }^{[8]}$ identified $\mathrm{Ca}^{2+}$ as the primary ion responsible for inhibiting hatch of salmonid eggs exposed during fertilization. Erickson et al. ${ }^{[9]}$ found that the addition of potassium chloride markedly increased copper toxicity, while addition of calcium chloride and sodium chloride substantially reduced it. Stekoll et al ${ }^{[8]}$ reported that spermatozoa activity was inhibited when small quantities of potassium chloride $\left(19.2 \mathrm{mg} \mathrm{L}^{-1}\right)$ or potassium carbonate $\left(106.2 \mathrm{mg} \mathrm{L}^{-1}\right)$ were added. The current standards of using TDS might be reconsidered to monitor specific ions in light of future risk assessments.

\section{MATERIALS AND METHODS}

In order to assess gaps in knowledge and new developments in methodology regarding TDS in Alaska waters, we examined the peer-reviewed literature and official reports to compile available data on toxicity related to TDS. Over forty reports, abstracts and papers were examined which document the effects of elevated TDS on fish spawning and rearing, aquatic invertebrates and aquatic vertebrates. The information is summarized in tables reporting the toxicity of TDS, including the species and life stage tested, the concentration producing the effect and the endpoint. This framework and interpretation of the literature is based on the long experience of the authors.

\section{RESULTS}

Invertebrates: Authors have reported a wide range of toxicity (either EC50 or LC50) for aquatic invertebrates, depending on species and especially, on the type of ion (Table 1 and 2). Chapman et al. ${ }^{[9]}$ exposed chironomid (Chironomus tentans) larvae to two synthetic TDS mixtures modeled after the ionic composition of two mine effluents from Alaskan mining operations. The TDS was primarily $\mathrm{CaSO}_{4}$. They reported significant effects in the chironomid larvae above $1100 \mathrm{mg} \mathrm{L}^{-1}$. Hoke et al. ${ }^{[10]}$ reported a 48 - h LC50 of $735 \mathrm{mg} \mathrm{L}^{-1}$ for C. dubia exposed to $\mathrm{NaHCO}_{3}$ and a 48-h LC50 $>5000 \mathrm{mg} \mathrm{L}^{-1}$ for Daphnia magna exposed to $\mathrm{NaCl}$.

Mount et al. ${ }^{[7]}$ reported a wide range of toxicities for C. dubia and D. magna, depending on the ionic composition (Table 1). The researchers reported that mixtures of $\mathrm{KHCO}_{3}+\mathrm{K}_{2} \mathrm{SO}_{4}$ had the lowest 24-h and 48-h LC50 concentrations for C. dubia $\left(390 \mathrm{mg} \mathrm{L}^{-1}\right.$ for both 24-h and 48-h). Mixtures of $\mathrm{CaSO}_{4}$ and $\mathrm{K}_{2} \mathrm{CO}_{4}$ resulted in 24-h LC50 of $1140 \mathrm{mg} \mathrm{L}^{-1}$ and 48-h LC50 of 1130 for C. dubia. Other mixtures of ions resulted in LC50 concentrations in the range of 2,000 to $4,000 \mathrm{mg}$ $\mathrm{L}^{-1}$ and with some mixtures, even higher ${ }^{[7]}$.

Fish: Tests on salmonidae (trout, char, salmon, grayling, whitefish) exposure to high levels of TDS have yielded mixed results, depending upon when exposure occurred ${ }^{[10-14]}$. Chapman et al. ${ }^{[9]}$ exposed embryonic and juvenile rainbow trout $(O$. mykiss) to two synthetic TDS mixtures modeled after the ionic composition of two mine effluents from Alaskan mining operations. No significant effects of the exposures were found on the rainbow trout up to 2000 $\mathrm{mg} \mathrm{L}^{-1}$. Their results are consistent with the results of Stekoll et al.$^{[8,11]}$ for exposures after fertilization.

Stekoll, et al. ${ }^{[15]}$ exposed coho salmon embryos to elevated TDS during different life stages, from post fertilization to button-up fry. They found no significant increase in mortalities with higher concentrations of TDS and concluded that these life stages were unaffected by TDS exposure in either the short or long term. However, when the coho salmon (O. kisutch) were exposed at fertilization, higher concentrations resulted in reduced hatch rates and delayed hatch, as well as long-term effects on growth and development. They found coho salmon to be sensitive to TDS exposure at fertilization but not at other embryonic life stages or the juvenile stages from alevin to button- up. Eggs exposed at fertilization that hatched showed effects in later development, i.e., eggs exposed to higher concentrations (1875 and $2500 \mathrm{ppm}$ TDS) had high mortality rates between the eyed and alevin stages. In the 2500-ppm concentration range, they found 50\% mortality of the $50 \%$ that had been fertilized.

Brix and Grosell ${ }^{[16]}$ conducted similar studies on Dolly Varden (Salvelinus malma) and Arctic grayling (Thymallus arcticus). They reported an LOEC for Arctic grayling ranging from 254 to $>2782 \mathrm{mg} \mathrm{L}^{-1}$ TDS and an LOEC for Dolly Varden ranging from $>1704$ to $>1817$. Their results for Dolly Varden are similar to the results of Stekoll et al.$^{[11]}$ for Arctic char; Stekoll et al reported an LOEC of $1875^{[8]}$. The wide range in the LOEC for Arctic grayling is possibly related to the ripeness of the fish when eggs and milt were taken. 
Am. J. Environ. Sci. 3 (1): 1-6, 2007

Table 1: Studies of effects of elevated TDS on freshwater aquatic invertebrates

\begin{tabular}{|c|c|c|c|c|c|c|}
\hline Species & & $\begin{array}{c}\text { TDS } \\
\text { Components }\end{array}$ & \multicolumn{2}{|c|}{ Effects Unit } & $\begin{array}{c}\text { Effects Concentration } \\
\mathrm{mg} \mathrm{L}^{-1} \\
\end{array}$ & Reference \\
\hline $\begin{array}{l}\text { Chironomus } \\
\text { tentans }\end{array}$ & Diptera larvae & $\mathrm{CaSO}_{4}$ & Growth rec & by $45 \%$ & 2,089 & Chapman et al. ${ }^{[9]}$ \\
\hline C.tentans & Diptera larvae & $\mathrm{CaSO}_{4}$ & Reduce & ival & 1,750 and 2,240 & Chapman et al. ${ }^{[9]}$ \\
\hline C.tentans & Diptera larvae & $\mathrm{CaSO}_{4}$ & $10 \mathrm{day}$ & & 2,035 & $\mathrm{USEPA}^{[22]}$ \\
\hline C. tentans & Diptera larvae & $\mathrm{CaSO}_{4}$ & & & 1,598 & USEPA $^{[23]}$ \\
\hline $\begin{array}{l}\text { Cricotopus } \\
\text { trifascia }\end{array}$ & Diptera larvae & $\mathrm{K}^{+}$ & & & 1567 & Hamilton 1975 , cited in $\mathrm{ENSR}^{[24]}$ \\
\hline C. trifascia & Diptera larvae & $\mathrm{CL}^{-}$ & & & 1406 & Hamilton 1975 , cited in $\mathrm{ENSR}^{[24]}$ \\
\hline $\begin{array}{c}\text { Hexagenia } \\
\text { bilineata }\end{array}$ & Insect: mayfly & $\begin{array}{l}\mathrm{K}, \mathrm{Li}, \mathrm{Mg}, \mathrm{Mo}, \\
\mathrm{Na}, \mathrm{SO}_{4}, \mathrm{NO}_{3}\end{array}$ & $\begin{array}{r}15 \text { day } \\
\text { sur }\end{array}$ & $30 \%$ & 2,270 & Woodward et al..$^{[25]}$ \\
\hline H. bilineata & Insect: mayfly & $\begin{array}{c}\mathrm{K}, \mathrm{Li}, \mathrm{Mg}, \mathrm{Mo} \\
\mathrm{Na}, \mathrm{SO}_{4}, \mathrm{NO}_{3}\end{array}$ & $\begin{array}{l}30 \text { day } \\
\text { sur }\end{array}$ & $0 \%$ & 1,230 & Woodward et al..$^{[25]}$ \\
\hline $\begin{array}{c}\text { Hydroptila } \\
\text { angusta }\end{array}$ & Insect: caddisfly & $\mathrm{K}^{+}$ & & & 2316 & Hamilton 1975 , cited in $\mathrm{ENSR}^{[24]}$ \\
\hline $\begin{array}{l}\text { Hydroptila } \\
\text { angusta }\end{array}$ & Insect: caddisfly & $\mathrm{Cl}^{-}$ & & & 2077 & Hamilton 1975, cited in ENSR[ [24] \\
\hline $\begin{array}{c}\text { Dugesia } \\
\text { gonocephala }\end{array}$ & flatworm & $\mathrm{Cl}^{-}$ & Mo & & 1230 & Palladina 1980 , cited in $\mathrm{ENSR}^{[24]}$ \\
\hline Tubifex tubifex & $\begin{array}{l}\text { segmented } \\
\text { worm }\end{array}$ & & $\mathrm{K}^{+}$ & $\mathrm{EC}^{2} 0^{1}$ & 2000 & Khangarot 1991, cited in ENSR ${ }^{[24]}$ \\
\hline Tubifex tubifex & $\begin{array}{l}\text { segmented } \\
\text { worm }\end{array}$ & & $\mathrm{Ca}^{+2}$ & EC50 & 814 & Khangarot 1991, cited in ENSR ${ }^{[24]}$ \\
\hline $\begin{array}{l}\text { Cyclops } \\
\text { abyssorum } \\
\text { prealpinus }\end{array}$ & $\begin{array}{l}\text { cyclopoid } \\
\text { copepod }\end{array}$ & & $\mathrm{Mg}^{+2}$ & EC50 & 280 & Baudoin 1974, cited in ENSR ${ }^{[24]}$ \\
\hline $\begin{array}{l}\text { C.abyssorum } \\
\text { prealpinus }\end{array}$ & $\begin{array}{l}\text { cyclopoid } \\
\text { copepod }\end{array}$ & & $\mathrm{Ca}^{+2}$ & EC50 & 7000 & Baudoin 1974, cited in ENSR ${ }^{[24]}$ \\
\hline C. dubia & zooplankton & & & $\mathrm{LC} 50$ & 1,692 & Tietge and Hockett ${ }^{[26]}$ \\
\hline C. dubia & zooplankton & & $\mathrm{NaCl}$ & 48-hr, LC50 & 835 & Hoke et al. ${ }^{[10]}$ \\
\hline C. dubia & zooplankton & & $\mathrm{NaCl}$ & 48-hr, LC50 & 735 & Hoke et al. ${ }^{[10]}$ \\
\hline Cladoceran & zooplankton & & $\mathrm{CaSO}_{4}$ & LC50, 48-h & $>1,910$ & Mount et al. ${ }^{[7]}$ \\
\hline D. pulex & zooplankton & & $\mathrm{Ca}$, ion & EC50, 48-h & 499 & Goodfellow et al. ${ }^{[27]}$ \\
\hline D. magna & zooplankton & & & $\mathrm{LC} 50$ & 1,692 & Tietge and Hockett ${ }^{[25]}$ \\
\hline D. magna & zooplankton & $<24 \mathrm{~h}$ & $\mathrm{NaCl}$ & 48-hr, LC50 & 5015 & Hoke et al. ${ }^{[10]}$ \\
\hline D. magna & zooplankton & $<24 \mathrm{~h}$ & $\mathrm{NaCl}$ & 48-hr, LC50 & 5000 & Hoke et al. ${ }^{[10]}$ \\
\hline D. magna & zooplankton & 4th instar & $\mathrm{NaCl}$ & 48-hr, LC50 & 4000 & Hoke et al. ${ }^{[10]}$ \\
\hline D. magna & zooplankton & $<24 \mathrm{~h}$ & $\mathrm{NaHCO}_{3}$ & 48-hr, LC50 & 1400 & Hoke et al. ${ }^{[10]}$ \\
\hline D. magna & zooplankton & $<24 \mathrm{~h}$ & $\mathrm{NaHCO}_{3}$ & 48-hr, LC50 & 1150 & Hoke et al. ${ }^{[10]}$ \\
\hline D. magna & zooplankton & 7 day & $\mathrm{NaHCO}_{3}$ & 48-hr, LC50 & 1780 & Hoke et al. ${ }^{[10]}$ \\
\hline D. magna & zooplankton & 7 day & $\mathrm{NaHCO}_{3}$ & 48-hr, LC50 & 2200 & Hoke et al..$^{[10]}$ \\
\hline D. magna & zooplankton & 7 day & $\mathrm{NaHCO}_{3}$ & 48-hr, LC50 & 1250 & Hoke et al. ${ }^{[10]}$ \\
\hline D. magna & zooplankton & $<24 \mathrm{~h}$ & $\mathrm{NaHCO}_{3}$ & 48-hr, LC50 & 1160 & Hoke et al..$^{[10]}$ \\
\hline D. magna & zooplankton & $<24 \mathrm{~h}$ & $\mathrm{NaHCO}_{3}$ & 48-hr, LC50 & 1000 & Hoke et al. ${ }^{[10]}$ \\
\hline $\begin{array}{l}\text { Mysidopsis } \\
\text { bahia }\end{array}$ & $\begin{array}{l}\text { mysid } \\
\text { shrimp }\end{array}$ & & $\mathrm{Ca}$, ion & LC50, 96-h & 927 & Goodfellow et al..$^{[27]}$ \\
\hline
\end{tabular}

LC50 $=$ Lethal Concentration 50, or concentration causing 50\% mortality

IC $0=$ Inhibition Concentration 0 , or concentration causing inhibition of $0 \%$ of the population.

EC50 $=$ Effects Concentration, or concentration effecting $50 \%$ of the population.

Ketola et al. ${ }^{[12]}$ found that exposing salmonid embryos to high concentrations of calcium $\left(520 \mathrm{mg} \mathrm{L}^{-1}\right.$ or greater) during water hardening (post-fertilization) decreased survival rates of several salmonid species. They ${ }^{[12]}$ reported 38\% survival at eye up for Salvelinus fontinalis exposed to $2229 \mathrm{mg} \mathrm{L}^{-1} \mathrm{CaSO}_{4}, 35 \%$ survival 
Am. J. Environ. Sci. 3 (1): 1-6, 2007

Table 2: Studies of effects of elevated TDS on aquatic plants, algae and bacteria reported in published literature

\begin{tabular}{|c|c|c|c|c|c|}
\hline Species & $\begin{array}{c}\text { Effects } \\
\text { Concentration } \\
\mathrm{mg} / \mathrm{L} \\
\end{array}$ & $\begin{array}{c}\text { TDS } \\
\text { Components }\end{array}$ & Effects Unit & Notes & Reference \\
\hline $\begin{array}{l}\text { Algae, species not } \\
\text { given }\end{array}$ & $>1400$ & Not specified & & Decline in productivity & $\begin{array}{c}\text { Kerekes and Nursall }{ }_{a l}^{[28]} \text { in Sorensen } e t \\
\end{array}$ \\
\hline $\begin{array}{l}\text { Selanastrum } \\
\text { capricornutum }\end{array}$ & 551.3 & $\mathrm{CaSO} 4$ & $\mathrm{EC} 20$ & $\begin{array}{c}\text { All sample } \\
\text { concentrations resulted } \\
\text { in toxic effects }\end{array}$ & LeBlond $^{[20]}$ \\
\hline S. capricornutum & $250-500$ & & & Inhibition of growth & $\begin{array}{r}\text { Cleave et al. 1976, in Sorensen et } \\
a l^{[19]}\end{array}$ \\
\hline S. capricornutum & $\geq 2020$ & $\mathrm{CaCO}_{4}$ & $\begin{array}{l}\text { Growth } \\
\text { inhibition }\end{array}$ & $\begin{array}{l}\text { No toxic effects at } 99 \text {, } \\
664,1180 \text {, or } 1640\end{array}$ & EVS Environment Consultants ${ }^{[29]}$ \\
\hline $\begin{array}{l}\text { Nitrogen-fixing } \\
\text { bluegreen bacteria }\end{array}$ & $\sim 2450$ & TDS & & Nitrogen fixation limited & Evans and Prepas ${ }^{[22]}$ \\
\hline Vibrio fischeri & 1960 & $\mathrm{CaSO}_{4}$ & $\mathrm{EC} 20$ & Inhibited growth & LeBlond and Duffy ${ }^{[21]}$ \\
\hline $\begin{array}{l}\text { Ceratophyllus } \\
\text { demersu, }\end{array}$ & 1170 & & & $\begin{array}{l}\text { elimination of sensitive } \\
\text { species }\end{array}$ & Hallock and Hallock $^{[5]}$ \\
\hline Typha sp & 1170 & & & $\begin{array}{l}\text { elimination of sensitive } \\
\text { species }\end{array}$ & Hallock and Hallock ${ }^{[5]}$ \\
\hline
\end{tabular}

Table 3: The most toxic ions or combinations of ions identified by Mount et al (1997). Ions are ordered from most toxic to least toxic for each species

\begin{tabular}{lll}
\hline Ceriodaphnia dubia & Daphnia magna & Fathead minnow \\
\hline 24-h test & 24-h test & $96-\mathrm{h}$ test \\
$\mathrm{KHCO}_{3}+\mathrm{K}_{2} \mathrm{SO}_{4}$ & $\mathrm{KHCO}_{3}+$ & $\mathrm{KHCO}_{3}$ \\
& $\mathrm{~K}_{2} \mathrm{SO}_{4}$ & \\
$\mathrm{KHCO}_{3}+\mathrm{KCl}$ & $\mathrm{KHCO}_{3}$ & $\mathrm{~K}_{2} \mathrm{SO}_{4}$ \\
$\mathrm{~K}_{2} \mathrm{SO}_{4}+\mathrm{KCl}$ & $\mathrm{KCl}$ & $\mathrm{KHCO}_{3}+\mathrm{K}_{2} \mathrm{SO}_{4}$ \\
$\mathrm{KCl}$ & $\mathrm{K}_{2} \mathrm{SO}_{4}+\mathrm{KCl}$ & $\mathrm{KHCO}_{3}+\mathrm{NaHCO}_{3}$ \\
$\mathrm{KHCO}$ & $\mathrm{KHCO}_{3}+\mathrm{KCl}$ & $\mathrm{K}_{2} \mathrm{SO}_{4}+\mathrm{KCl}$ \\
$\mathrm{K}_{2} \mathrm{SO}_{4}$ & $\mathrm{~K}_{2} \mathrm{SO}_{4}$ & $\mathrm{KHCO}_{3}+\mathrm{KCl}$ \\
$\mathrm{MgCl}_{2}+\mathrm{KHCO}_{3}$ & & $\mathrm{NaHCO}$ \\
$\mathrm{KHCO}_{3}+\mathrm{NaHCO}_{3}$ & & $\mathrm{KCl}$ \\
$\mathrm{MgSO}_{4}+\mathrm{KHCO}_{3}$ & & \\
\hline
\end{tabular}

for Salmo solar exposed to $1395 \mathrm{mg} \mathrm{L}^{-1} \mathrm{CaCL}$ and $4 \%$ survival for $O$. mykiss exposed to $1500 \mathrm{mg} \mathrm{L}^{-1} \mathrm{CaSO}_{4}$. In Ketola et al.'s study, ${ }^{[12]}$ eggs were dry fertilized (fertilized in the presence of ovarian and seminal fluids only), while embryos in Stekoll et al.'s study ${ }^{[1]}$ were fertilized in control or exposure waters. Both studies rinsed fertilized embryos in exposure waters.

Brannock et $a l^{[17]}$ examined the individual ionic components of a TDS mixture and the effect of those ions on the fertilization rates of king and pink salmon (O. gorbuscha). The ions were tested individually at levels equivalent to Stekoll et al.'s 2500-ppm simulation, ${ }^{[11]}$ also at one quarter of the concentration and at four times the concentration. Fertilization rates in both the king and pink salmon were significantly lower with exposure to either calcium or sulfate at $2500 \mathrm{ppm}$ TDS equivalent. Potassium and magnesium ions showed no detectable differences from the control at 2500 ppm TDS equivalent. This work pointed to calcium or possibly sulfates as being the likely cause of lowered fertilization rates.
Mount et $a{ }^{[7]}$ examined the toxicity of different combinations of ions to fathead minnows, in test similar to those conducted with C. dubia and D. magna. Results with the fathead minnows were similar to results with the invertebrates, producing a wide range of LC50 values, depending on ionic composition. Of the 30 combinations of ions reported by Mount et al., one (KHCO3) had a 96-h LC50 <510 mg L $\mathrm{L}^{-1}, 7$ combinations resulted in 96-h LC50 concentrations that were less than $1000 \mathrm{mg} \mathrm{L}^{-1}$ and a number of ionic combinations resulted in 96-h LC50 values higher than $2000 \mathrm{mg} \mathrm{L}^{-1}$. Mount et al. ${ }^{[7]}$ did not test toxicity on reproduction or early development; their tests were limited to mortality of mature fish.

Aquatic plants, algae and bacteria: Few studies were found that documented effects of elevated TDS or of different ions on aquatic plants and algae (Table 2). Kerekes and Nursall (cited in Sorensen et al. ${ }^{[18]}$ ) found lower productivity in algae at TDS concentrations $>1400 \mathrm{mg} \mathrm{L}^{-1}$. LeBlond ${ }^{[19,20]}$ reported an EC20 = 551.3 for Selanastrum capricornutum. Evans and Prepas ${ }^{[21]}$ reported decreased nitrogen fixation in bluegreen bacteria exposed to approximately $2450 \mathrm{mg} \mathrm{L}^{-1} \mathrm{TDS}$. Hallock and Hallock ${ }^{[5]}$ reported the near elimination of coontail (Ceratophyllus demersum) and cattails (Typha sp.) in water with $1170 \mathrm{mg} \mathrm{L}^{-1} \mathrm{TDS}$.

\section{DISCUSSION}

The measurement of TDS integrates all anions and cations in the sample and some ions or combinations of ions are substantially more toxic than other ions or combinations of ions. A species might be more sensitive to TDS toxicity at certain life stages, as many fish are during fertilization. Therefore, a water quality 
Am. J. Environ. Sci. 3 (1): 1-6, 2007

standard for TDS can take several approaches: 1) The standard can be set low enough to protect all species and life stages exposed to the most toxic ions or combination of ions; 2) The standard can be set to protect most species and life stages for most ions and combinations of ions; or 3) Different limits can be defined for different categories of ions or combinations of ions, with a lower limit during fish spawning, if salmonid species that have been shown to be sensitive to TDS during fertilization and egg development are present.

Approach (1) may be unnecessarily restrictive, although simpler to define and implement. Approach (2), although less restrictive, may lead to adverse effects to aquatic communities. Approach (3) is more complicated to define and would require that the potential discharger determine the composition of the effluent and which species and life stages are present downstream of the effluent. Overall, Approach (3) would provide the greatest protection to aquatic species and the least unnecessary restriction to potential dischargers. The research of Mount et al. ${ }^{7}$ provides information on toxicity of different ions and ion combinations. Of the ions and combinations of ions tested by Mount, et al., ${ }^{7}$ the most toxic to C. dubia, D. magna and fathead minnows are shown on Table 3, ordered from most toxic to less toxic. All tests with these ions resulted in LC50 values less than $1,000 \mathrm{mg} \mathrm{L}^{-1}$.

The research of Stekoll et al. ${ }^{[11]}$ and Brix and Grosell $^{[17]}$ provide information on toxicity of TDS, mostly in the form of $\mathrm{CaSO}_{4}$, to some Alaska fish species, especially at fertilization. Using the results of Stekoll et al. ${ }^{[10]}$ and Brix and Grosell ${ }^{[17]}$ the fish species can be ordered from most sensitive to least sensitive (to $\mathrm{CaSO}_{4}$ TDS): O. keta ( chum Salmon) $>$ O. mykiss (steelhead salmon) $>$ Thymallus arcticus (Arctic grayling) > Salvelinus malma (Dolly Varden) > Salvelinus alpinus (arctic char).

\section{ACKNOWLEDGEMENTS}

The need for research on toxicity of total dissolved solids (TDS) arose from the concerns of the Alaska Departments of Fish and Game and Environmental Conservation, working in concert with the Alaska Council of Producers to revise discharge limits for total dissolved solids. Resource managers and representatives of industry were instrumental in initiating research projects to investigate possible effects of TDS to Alaska's important salmon resources. McKie Campbell led the team, which secured funding for the initial research from the Alaska Science and Technology Foundation (ASTF). Dr. Alvin G. Ott, now Operations Manager, of Office of Habitat Management and Permitting, Alaska Department of Natural Resources, recognized egg fertilization and early development as the most probable sensitive life stage of salmonid fish. Dr. Mike Stekoll and his fellow researchers from the University of Alaska Southeast designed test systems for salmon egg fertilization and early development. They also developed a short-term fertilization/initial egg development test that could be used to test toxicity of different ionic combinations. They also identified fish species that were most sensitive to elevated TDS. Their research remains a valuable contribution. Mr. Tom Irwin and Mr. Bill Jeffress represented the interests of the hard rock mining industry; without their concern about TDS toxicity and encouragement the initial ASTF studies would not have occurred. This review and report was funded by a grant from Alaska Department of Environmental Conservation, through the University of Alaska Fairbanks. Thanks go to Nancy Sonafrank, ADEC, for facilitating the grant, to Judie Triplehorn, UAF, for her library searches and for supplying many of the papers in the report.

\section{REFERENCES}

1. U.S. Environmental Protection Agency, Office of Water, 1986. Quality Criteria for Water (Gold Book). EPA 440/5-86-001. Washington D.C.

2. American Public Health Association (APHA), 1992. Standard Methods for the Examination of Water and Wastewater. $18^{\text {th }}$ Edn.

3. Wetzel, R.G., 1983. Limnology. Sec. Ed.n. Saunders College Publishing, NY, pp: 767.

4. Bierhuize,n J.F.H. and E.E. Prepas, 1985. Relationship between nutrients, dominant ions and phytoplankton standing crop in prairie saline lakes. Can. J. Fish. Aquat. Sci., 42: 1588-1594.

5. Hallock, R.J. and L.L. Hallock (Ed.), 1993. Detailed Study of Irrigation Drainage in and near Wildlife Management Areas, West-Central Nevada, 1987-90. Part B. Effect on Biota in Stillwater and Fernley Wildlife Management Areas and other Nearby Wetlands. US Geological Survey, Water Resources Investigations Report 92-4024B.

6. Derry, A.M., E.E. Prepas and P.D.N. Hebert, 2003. A comparison of zooplankton communities in saline lakewater with variable anion composition. Hydrobiologia, 505: 199-215.

7. Mount, D.R., D.D. Gulley, J.R. Hockett, T.D. Garrison and J.M. Evans, 1997. Statistical models to predict the toxicity of major ions to C. dubia, Daphnia magna and Pimephales promelas (Fathead Minnows). Environ. Toxicol. Chem., 16: 2009-2019.

8. Stekoll, M., W. Smoker, I. Wang and B. Failor, 2003a. Final report for ASTF grant \#98-1-012. Salmon as a bioassay model of effects of total dissolved solids. Juneau, Alaska, University of Alaska - Fairbanks, pp: 87. 
Am. J. Environ. Sci. 3 (1): 1-6, 2007

9. Chapman, P.M., H. Bailey and E. Canaria, 2000. Toxicity of total dissolved solids associated with two mine effluents to chironomid larvae and early lifestages of rainbow trout. Environ. Toxicol. Chem., 19: 210-214.

10. Hoke, R.A., W.R. Gala, W.R., J.B. Drake, J.P. Geisy and S. Fleger, 1992. Bicarbonate as a potential confounding factor in cladoceran toxicity assessments of pore water from contaminated sediments. Can. J. Fish. Aquat. Sci., 49: 16331640 .

11. Stekoll, M., W.Smoker, I. Wang and W. Hayes, 2003 b. Final report on the effects of total dissolved solids on fertilization rates of salmonids in the Red Dog Mine area. Juneau, Alaska, University of Alaska - Fairbanks, pp: 27.

12. Ketola, H.G., D. Longacre, A. Greulich, L. Phetterplace and R. Lashomb, 1988. High Calcium Concentration in Water Increases Mortality of Salmon and Trout Eggs. Progressive Fish-Culturist, 50: 129-135.

13. Weber Scannell P. and L. Jacobs. 2001. Effects of Total Dissolved Solids on Aquatic Organisms: A Literature Review. Alaska Dept. of Fish and Game Tech. Report 01-06. Juneau, AK, pp: 68.

14. Erickson, R.J., D.A. Benoit, V.R. Mattson, H.P. Nelson Jr. and E.N. Leonard, 1996. The effects of water chemistry on the toxicity of copper to fathead minnows. J. Environ. Toxicol. Chem., 15: 181-193.

15. Stekoll, M., W. Smoker, I. Wang and B. Failor, 2001. Fourth Quarter 2000 Report for ASTF Grant \#98-012, Project: Salmon as a Bioassay Model of Effects of Total Dissolved Solids. 17 January 2001.

16. Brix, K.V. and M. Grosell, 2005 Report on the effects of total dissolved solids on arctic grayling and dolly varden fertilization success. Teck Cominco Red Dog Mine, Kotzebue, AK.

17. Brannock, P., M.S. Stekoll, B. Failor and I. Wang. 2002. Salt and salmon: The effects of hard water ions on fertilization. Aquatic Sciences Meeting. American Society of Limnology and Oceanography. Feb. 11-15, pp: 142.

18. Sorensen, D.L., M. McCarthy, E.J. Middlebrooks and D.B. Porcella, 1977. Suspended and dissolved solids effects on freshwater biota: A review. US Environmental Protection Agency, EPA-600/3-77042.

19. LeBlond, J.B., 2000. A Toxicity Assessment of Total Dissolved Solid Ions in Mine Effluent Using Two Common Bioassays: The 22-hr MicroTox® Assay and a S. Capricornutum Growth Assay. April 2000. M. S. Thesis, University of Alaska Fairbanks, Fairbanks, Alaska.
20. LeBlond, J.B. and L.K. Duffy, 2001. Toxicity assessment of total dissolved solids in effluent of Alaskan mines using 22-h chronic Microtox ${ }^{\circledR}$ and Selenastrum capricornutum assays. Sci. Tot. Environ., 1-3: 49-59.

21. Evans, J.C. and E.E. Prepas, 1996. Potential effects of climate change on ion chemistry and phytoplankton communities in prairie saline lakes. Limnol. Oceanogr., 41: 1063-1076.

22. U.S. Environmental Protection Agency, Office of Water, 1999. National Recommended. Water Quality Criteria - Correction. EPA 822-Z-99-001. April 1999.

23. U.S. Environmental Protection Agency, Region 10 Laboratory, February 19, 1999. Memorandum from M.K. Parker Manchester Laboratory Chemist, to Mike Letourneau, EPA Region 10 Project Manager, conveying a quality assurance data review of chemistry analyses conducted at Manchester Laboratory.

24. ENSR, 1997. Review of toxicity studies conducted on Kensington Mine effluent. Doc. No. 2012-001-200.

26. Teitge, J.E. and J.R. Hockett, and J.M. Evans, 1996. Major Ion Toxicity of Six Produced Waters to Three Freshwater Species: Application of Ion Toxicity Models and TIE Procedures. Environ. Toxicol. Chem., 16: 2002-2008.

25. Woodward, D.F., R.G. Riley, M.G. Henry, J.S. Meyer, and T.R. Garland, 1985. Leaching of Retorted Oil Shale: Assessing the Toxicity to Colorado Squawfish, Fathead Minnows, and Two Food-Chain Organisms. Trans. Am. Fish. Soc., 114: 887-894.

27. Goodfellow, W.L., L.W. Ausley, D.T. Burton, D.L. Denton, P.B. Dorn, D.R. Grothe, M.A. Heber, T.J. Norberg-King, and J.H. Rodgers Jr., 2000. Major ion toxicity in effluents: a review with permitting recommendations. Issn: 1552-8618. J. Environ. Toxicol. Chem., 19: 175-182.

28. Kerekes, J. and J.R. Nursall, 1966. Eutrophication and senescence in a group of Prairie-Parkland Lakes in Alberta, Canada. Verhandlungen der Internationalen Vereinigung fur theoretische und angewandte Limnologie, 16: 65-73.

29. EVS Environment Consultants, 1997c. Toxicity of Total Dissolved solids (TDS) in Coeur Mine Effluent: Selenastrum capricornutum. Laboratory Report prepared for Coeur Alaska, Juneau, AK, pp: 10 . 